\title{
PHALERAE FROM THE MOUND SADOVY AND THE IMAGE OF THE 'TARANDRUS'
}

\author{
Irina P. Zasetskaya \\ State Hermitage Museum, Saint Petersburg, Russian Federation
}

\begin{abstract}
This paper is devoted to the content of the composition on the phalerae from the mound Sadovy and to the related issue about the existence of the 'tarandrus' image in the art of Eurasian nomads. L. S. Klein identifies one of the depicted characters with the mythical tarandrus and considers the images on the waistbands from Siberian collection and the collection of the Katandinsky mound (the $5^{\text {th }}-3^{\text {rd }} \mathrm{cc}$. BC) as its prototypes. On the basis of this assumption, L.S. Klein draws conclusion that the movement of Sarmatians to the West took place from the areas of the Irtysh and Ishim rivers. According to the descriptions by the ancient authors, the tarandrus looks like a large hoofed animal from the deer family and has a special power to change its color according to the environment. L.S. Klein's definition of the tarandrus as a mythical deer with the characteristics of four different animals has been rejected by the written sources. Ancient authors compared the tarandrus to an ox just to underline a big size of this animal. A comparative analysis of stylistic features and the plot's content show that the studied items had presented different images and scenes. The items which contain the images of animals are important sources for studying the history of nomads. Hence, their wrong interpretation can cause visual and historical mistakes.
\end{abstract}

Key words: the mound Sadovy, plot, animal style, ancient authors, phalerae, Pliny the Elder, Aristotle.

Citation. Zasetskaya I.P. Phalerae from the Mound Sadovy and the Image of the 'Tarandrus'. Vestnik Volgogradskogo gosudarstvennogo universiteta. Seriya 4, Istoriya. Regionovedenie. Mezhdunarodnye otnosheniya [Science Journal of Volgograd State University. History. Area Studies. International Relations], 2018, vol. 23, no. 3, pp. 126-137. (in Russian). DOI: https://doi.org/10.15688/jvolsu4.2018.3.11

УДК 903'1(470+571):685.1

Дата поступления статьи: 20.02.2018

ББК 63.442(2)-413

Дата принятия статьи: 10.04.2018

\section{ФАЛАРЫ ИЗ КУРГАНА САДОВЫЙ И ОБРАЗ «ТАРАНДРА»}

\author{
Ирина Петровна Засецкая \\ Государственный Эрмитаж, г. Санкт-Петербург, Российская Федерация
}

\begin{abstract}
Аннотация. Настоящая статья посвящена содержанию композиции на фаларах из кургана Садовый и в связи с этим вопросу о существовании в искусстве кочевников Евразии образа «тарандра». Л.С. Клейн отождествил одного из персонажей на изображениях из кургана Садовый с «мифическим тарандром», а в качестве прототипов рассматривает изображения на поясных пластинах из Сибирской коллекции и Катандинского кургана (V-III вв. до н. э.). На этом основании Л.С. Клейн заключает, что движение сарматов на запад происходило из области Поиртышья и Поишимья. Судя по описаниям античных авторов, тарандр предстает перед нами в виде крупного парнокопытного животного из семейства оленей, обладающего особым даром $\infty$ менять свою окраску в соответствии с окружающей природной средой. Данное же Л.С. Клейном определе§ источниками. А сравнение тарандра с быком античные авторы приводят лишь для того, чтобы подчеркнуть его большие размеры. Сравнительный анализ стилистических признаков и содержания сюжетов показал, что на указанных предметах представлены разные образы и разные по содержанию сцены. Поскольку предметы с изображениями звериного стиля наряду с другими видами древних находок являются одним из источников 己 изучения истории кочевых племен, то неправильное осмысление зооморфных образов, как мы видим, мо() жет привести к неправильным выводам не только изобразительного, но и исторического характера.
\end{abstract}


Ключевые слова: курган Садовый, сюжет, звериный стиль, античные авторы, фалар, Плиний Старший, Аристотель.

Цитирование. Засецкая И. П. Фалары из кургана Садовый и образ «тарандра» // Вестник Волгоградского государственного университета. Серия 4, История. Регионоведение. Международные отношения. - 2018. T. 23, № 3. -C. 126-137. - DOI: https://doi.org/10.15688/jvolsu4.2018.3.11

Курган Садовый, когда-то возвышавшийся на окраине г. Новочеркасска, был исследован в 1962 г. археологической экспедицией ЛОИА АН СССР и Ростовского областного музея краеведения под началом научного сотрудника института С.И. Капошиной [6]. Непосредственно раскопками кургана руководил Л.С. Клейн - доцент исторического факультета на кафедре археологии ЛГУ.

Курган ко времени раскопок имел высоту 2,2 м, диаметр 44-48 м (рис. 1). Могила, расположенная в центре кургана, была разграблена, но найденные за пределами могильной ямы золотые изделия, импортная серебряная и бронзовая посуда, бронзовый котел, железный умбон от щита, глиняная амфора и др. свидетельствуют, что здесь был похоронен представитель знатного, а возможно, и царского рода $[8$, с. 100-115].

Одной из интереснейших находок является богатый набор конской упряжи, состоящий из двух больших наплечных фаларов и двенадцати малых от уздечных ремней, исполненных в сарматском полихромном зверином стиле.

Декоративное оформление больших фаларов состоит из композиции, выполненной в три яруса. В центре - медальон с изображением сцены терзания или жертвоприношения. В качестве жертвы выступает кошачий хищник пантера или тигр, которого терзают волк и грифон. Сцена отделена от остальной части декора кольцом в виде неглубокой бороздки. Вокруг нее расположен фриз, состоящий из пяти пар сидящих напротив друг друга пантер и помещенных между ними головами еще от пяти пантер. Парные фигуры хищников изображены в профиль с головой в фас, показаны три лапы с каплеобразными вставками на конце, направленными к центру, образуя таким способом вокруг медальона орнаментальный бордюр. Головы всех пятнадцати пантер одинаковы по размерам, показаны в фас и расположены на одном уровне, представляя самостоятельную композиционную и смысловую часть декора. Второй фриз из 20 голов фантастической птицы или грифона, расположенный по внешнему краю изделия, замыкает композицию в целом. Одним из главных стилистических приемов в изображении персонажей является интенсивное использование вставок, в основном из бирюзы (судя по рисунку, вставок было около 216 штук), которыми подчеркнуты глаза, уши, щеки (у грифонов), бедра, плечи и окончание лап ${ }^{1}$. Вставки расположены в углубленных гнездах каплевидной, сегментовидной (уши у пантер) и миндалевидной формы. Почти полностью отсутствует графический орнамент. Только шерсть на ногах центральной пантеры и у некоторых фигур второго яруса, а также на спине волка показана валиками в виде «веревочêè» (ðѐñ. 2, a). Фалары состоят из бронзовой пластинчатой основы, золотого рельефного покрытия и промежуточного смолистого вещества. Судя по аналогичным изделиям, можно предположить, что рельеф на фаларах исполнен в технике басмы с одной матрицы. Промежуточное вещество, заполняющее рельеф, сначала использовалось в качестве опоры для обработки декора с лицевой стороны, предохраняя тем самым золотое покрытие от повреждений. В дальнейшем, это вещество, оставаясь на месте, служило для защиты рельефа и формы предмета. Верхняя декоративная часть фалара соединялась с нижней пластиной при помощи загнутых краев золотого покрытия, охватывающих и плотно прилегающих к бронзовой основе. На оборотной стороне имеются три петли (одна наверху и две по бокам). Петли согнуты из узкой пластины, концы их расплющены и приклепаны.

Сохранившиеся в целостности малые фалары состоят из металлической пластинчатой основы (на 4 экземплярах из бронзы, на других 4 из серебра, и еще 4 фалара, укрепленные на концах железных псалий, имеют железные основы) и декоративного золотого покрытия. На оборотной стороне припаяна петля. Фалары украшены сценой терзания, 
аналогичной композиции на центральном медальоне больших фаларов. Изображение исполнено в сарматском полихромном зверином стиле и инкрустировано вставками бирюзы и кораллов (рис. 2, б).

Декор на больших и малых фаларах, с одной стороны, характеризуется яркостью оформления за счет сочетания золота с цветной инкрустацией, но с другой - передача образов и сцен достаточно схематична и условна. О том, что на медальоне и малых фалаpax воспроизведен мотив терзания, можно судить лишь по расположению фигур - в центре распластанная фигура пантеры, слева от нее грифон, голова которого лежит на ее спине, справа - волк (?), морда которого упирается в заднюю ногу пантеры. Но, несмотря на схематизацию образов (фигуры искажены, нарушены пропорции, контуры прослеживаются слабо), построение сцен (прежде всего это касается больших фаларов) хорошо организовано, все компоненты связаны между собой, образуя единое целое [5, с. 100-101, рис. 2, 1].

Семантика изображений на больших фаларах непроста. Кажется несомненным, что на них представлен единый сюжет, передающий ритуальное действие, которое, скорее всего, имеет отношение к обряду жертвоприношения. В связи с этим возникает много вопросов: например, как связаны пантеры внутреннего круга, обращенные мордами к медальону, с центральной сценой, в которой терзают или приносят в жертву их сородича; какому божеству посвящается этот ритуал; почему сцена на медальоне заключена в тройной круг и какова его роль, должен ли он что-то охранять (например, совершающийся обряд) или его функция была другой?

Сцены терзания - один из самых распространенных мотивов в древнем искусстве кочевников Евразии скифской эпохи, к которым исследователи относят композиции из двух персонажей, представленных нападающим и его жертвой, борьбы двух животных и изображений культового характера с участием трех или четырех фигур. Вот почему в научной литературе им уделено наибольшее внимание, в том числе и происхождению символики.

Мнения исследователей в основном разделились между тремя концепциями: тотемистической, представляющей борьбу двух то- темов, родоначальников в образах животных; магической, объясняющей, что подобные сцены наносились на предмет с целью придать ему магические свойства; и мифологический, отражающий мировоззренческую идею «жизнь, смерть, возрождение». Однако, как справедливо заметила Е.Ф. Королькова, мифологическая концепция, которая признается большинством ученых, не исключает присутствия в рассматриваемых сценах символики магического и тотемистического значения [9, с. 130-133]. В качестве подтверждения этой мысли, по моему мнению, может служить композиция на больших фаларах из Садового кургана, в которой, скорее всего, был представлен мифологический сюжет, связанный с ритуальным обрядом жертвоприношения, восходящим к традициям тотемистических воззрений, а наличие кругов вокруг центральной сцены можно отнести к магическим символам защиты.

В восстановлении образов и понимании сюжета на медальоне больших фаларов и на малых уздечных бляхах нам помогает сцена на золотых поясных пластинах III-II вв. до н. э. из Сибирской коллекции, на которых представлена композиция из трех фигур - волкоподобного чудовища и грифона, терзающих тигра (рис. 2, в) [3, с. 47-48].

Исследованию данного мотива посвятил свою статью Л.С. Клейн, в которой он рассматривал истоки происхождения композиции в целом и одного из образов в сцене терзания на фаларах из Садового и сибирских пластинах [7, с. 228-234]. Исследуя сюжеты на этих находках, он справедливо отмечает, что по сравнению с «чистыми» сибирскими образами фигуры на фаларах искажены и деградированы, и объясняет подобное явление отрывом мастера от истоков иконографической традиции. При этом он полагает, что один из персонажей (фигура слева - на сибирской пластине и справа - на фаларах) соответствует образу «тарандра древних авторов» и представляет «мифического оленя, соединившего четыре разных животных» [7, с. 229]. На мой взгляд, вряд ли можно согласиться с таким определением. В связи с этим вновь обратимся к античным письменным источникам, в которых имеются сведения об этом «фантастическом» существе. 
Аристотель (IV в. до н. э.) в своем трактате «О чудесных слухах» писал: «Рассказывают, что у скифов, называемых гелонами, водится редкое животное, которое называется тарандром. Говорят, что оно меняет цвет шерсти, смотря по месту, где находится; поэтому трудно ловить его, так как цвет его шерсти уподобляется цвету деревьев, местностей и вообще всего, что его окружает; весьма удивительно, что оно меняет цвет шерсти, так как прочие животные меняют цвет кожи, как например, хамелеон и полип; величиною оно с быка, а складом головы похоже на оленя» (цит. по: [10, с. 379-380]).

Теофаст в сочинении «О водах» пишет: «Меняет цвет и уподобляется растениям или местности, или камням, к которым приблизятся, полип, хамелеон и животное тарандр, которое, как говорят, водится в Скифии или Сарматии. Таранд величиною с быка, а мордою похож на оленя, только шире, так что она как бы сложена из двух оленьих морд. Животное это двукопытное (парнокопытное. - И. 3.) и рогатое. Рог имеет отростки, как олений, и весь покрыт шерстью, кость его обтянута кожею, откуда и растет шерсть. Кожа толщиной с палец и очень крепка, почему ее высушивают и делают из нее панцири» (цит. по: $[10$, c. 388$])$.

Сведения о тарандре находим и в сочинении Плиния Старшего «Естественная история» (середина I в. н. э.). Он отмечает, что тарандр «величиною с быка, голова его больше оленьей, но похожа на нее, рога ветвистые, копыта двойные, шерсть длиною с медвежью, но цветом похожа на ослиную, если животное сохраняет свой естественный цвет. Кожа так тверда, что из нее делают панцири. Будучи испугано, животное принимает цвет всех деревьев, кустов, цветов и вообще всех мест, в которых прячется, и потому ловится редко» (цит. по: [11, с. 188-189]).

Таким образом, судя по описаниям античных авторов, тарандр предстает перед нами в виде крупного парнокопытного животного из семейства оленей, обладающего особым даром менять свою окраску в соответствии с окружающей природной средой. Данное же Л.С. Клейном определение тарандра как мифического оленя, соединившего четыре разных животных, опровергается письменными источ- никами. А сравнение тарандра с быком античные авторы приводят лишь для того, чтобы подчеркнуть его большие размеры.

В качестве прототипов «сарматского тарандра» Л.С. Клейн рассматривает зооморфные фигуры на золотой застежке из УланУде и деревянной застежке из Катандинского кургана V-III вв. до н. э., на которых, как он пишет, представлены «сюжеты борьбы зверей», прошедшие «ряд этапов последовательного развития и деградации... - от Катандинской и Верхнеудинской застежек, через гагаринские бляхи Сибирской коллекции к фаларам Садового кургана. Процесс растянулся на 5-6 веков, и за это время мотив передвинулся из Забайкалья, Алтая и Поишимья в донские степи» [7, с. 229-231, рис. 1]. Но, на мой взгляд, не все выглядит так однозначно. Прежде всего, следует отметить, что представленные на рисунке 1 в публикации Л.С. Клейна композиции воспроизводят разные сюжеты (рис. 3). Например, на улан-удинской и катакандинской застежках показаны сцены нападения хищного зверька на крупного животного (рис. $3,4,5$ ); на сибирских поясных бляхах в одном случае изображена борьба зверей (рис. 3, 3), а в другом - сцена жертвоприношения или терзания (рис. 3,2 ). Что же касается персонажей этих сцен, они представлены разными зооморфными образами. Даже на застежках, несмотря на одинаковое композиционное решение сюжета, так называемые тарандры относятся к разным видам: на уланудинской изображена лошадь с ветвистыми рогами в виде голов грифона, на катандинской - копытное животное (олень или лось) с длинным хвостом хищника и головками грифона на хвосте и рогах.

Совершенно другие образы показаны на золотых изделиях из Сибирской коллекции Петра I. На пластине со сценой борьбы зверей участвуют два персонажа - тигр и, по определению С.И. Руденко, фантастический волк с поднятым кверху хвостом, заканчивающимся головкой грифона и гребнем вдоль спины из таких же головок. На пластине со сценой терзания в качестве жертвы выступает тигр, на которого напали грифон и чудовище, подобное вышеописанному фантастическому волку. В результате остается неясным, какое же существо следует называть тарандром: ло- 
шадь с рогами, оленя-лося с хвостом хищника или фантастического волка. Лишь одна черта - наличие головок грифона в качестве изобразительного приема - объединяет перечисленных выше претендентов на роль тарандра. Но эта черта в скифскую эпоху была известна в изображении разных животных и птиц, что никак не может быть опознавательным признаком именно тарандра. Таким образом, предложенная Л.С. Клейном хронологическая цепь развития данного образа, на мой взгляд, фактически не существует.

И уж совсем непонятно, какое существо мы должны называть «сарматским тарандром». Л.С. Клейн замыкает хронологическую цепь «тарандров» одним из участников сцены терзания на фаларах из Садового (персонаж справа), в котором можно видеть стилизованную фигуру фантастического волка из композиции на сибирских пластинах. Сцена на фаларах передает традиционный мотив, являясь в данном случае более поздней репликой сюжета на сибирских поясных пластинах. Исследование зооморфных изображений сарматского полихромного звериного стиля показало, что в изобразительном искусстве сарматов нет такого образа, который можно было бы отождествить с «мифическим тарандром» [12, кат. 45-108; 18].

Но, чтобы завершить тему тарандра, нельзя не упомянуть статью М.П. Завитухиной, посвященную стилистическим и техническим особенностям золотой застежки из Улан-Уде (Сибирская коллекция Петра I), которая известна как находка из Забайкалья [2, c. 143-148]. Несмотря на противоречивые сведения о месте и времени нахождения застежки (Забайкалье или Монголия), по справедливому мнению М.П. Завитухиной, изображение на ней относится к «центральноазиатскому очагу искусства звериного стиля», что подтверждается указанными автором аналогиями бронзовых поясных пластин хуннской эпохи из Забайкалья и Ордоса.

В описании улан-удинской застежки автор отмечает, что главным персонажем композиции является фантастический зверь, основу которого составляет реальное животное низкорослая степная лошадь, наделенная чертами других животных: птичьей клювовидной мордой, ветвистыми рогами оленя, каждый отросток которого заканчивается головками грифонов, тигриным хвостом с головкой грифона на конце. Кроме того, на теле лошади изображены бараньи и птичьи головы (их нет на рисунке в статье Л.С. Клейна) (ср. рис. 3, 4 и рис. $4, a)$.

М.П. Завитухина в указанной статье коснулась вопроса происхождения образа тарандра, справедливо полагая, что, исходя из сведений античных авторов, это мог быть либо олень, либо лось. Однако, далее ссылаясь на те же письменные источники, она пишет, что тарандр наделен «деталями, по крайней мере, четырех животных», главным из которых, вероятно, был лось. Но, как мы видели, у античных авторов нет никаких упоминаний о животных, якобы участвующих в создании «мифического тарандра». Что же касается непосредственно изображения на улан-удинской застежке, то М.П. Завитухина полагает, что представленный на ней зооморфный мотив является «восточной версией» образа тарандра. Поэтому, как она объясняет, здесь вместо лося показан конь местной породы с головой грифона, оленьим рогом, украшенным головами грифона [2, с. 146]. В таком случае мы можем любое фантастическое существо звериного стиля скифо-сарматской эпохи объявить тарандром и представить его как «местную версию» этого образа. Но ведь из письменных источников совершенно ясно, что речь идет о реальном животном, а указание на наличие у него оленьих ветвистых рогов и двойных копыт, а также на его большие размеры («величиной с быка») позволяет утверждать, что перед нами один из, возможно, редких видов семейства оленей.

Отсюда возникает первый вопрос: если под тарандром античные авторы подразумевали оленя крупной породы, то почему мы ищем его в каких-то фантастических зооморфных персонажах? И другой вопрос: а знали ли кочевники евразийских степей вообще о существовании какого-то «античного тарандра», и если да, то почему непременно должны были изображать его в виде чудовища, а не просто в виде фигуры оленя?

В связи с этим следует обратить внимание на указания античных писателей о месте обитания тарандра. Напомним слова Аристотеля «...у скифов, называемых гелонами, во- 
дится редкое животное, которое называется тарандр». Теофаст отмечает - «...животное таранд, которое, как говорят, водится в Скифии и Сарматии». Но особенно интересны сведения Стефана Византийского: «Гелон город в Европейской Сарматии, названный по имени Иеракловва сына Гелона, брата Агафирса: жители называются также... Город этот деревянный, лежащий в стране Будинов, великого народа, по словам Геродота. У них водится странное животное, называемое тарандом...» (цит. по: [10, с. 257-258]). Из приведенных отрывков ясно, что речь идет о животном, которое обитает не в Сибири, а водится на территории лесостепной Скифии, где, по словам Геродота, жили нескифские племена - невры, андрофаги, меланхлены, будины и гелоны.

Изделия изобразительного творчества, наряду с другими видами древностей, являются одним из источников изучения истории сарматских племен, населявших в первые века нашей эры, по сообщениям античных авторов, южнорусские степи.

Зооморфные образы в искусстве звериного стиля этого времени связаны с мировоззренческими взглядами кочевого общества, в котором сарматы играли не последнюю роль. Чтобы понять, о чем говорят эти древние изображения, нужна научная систематизация материала. При этом в первую очередь необходима проработка стилистических особенностей изображений, выделение и классификация их по отдельным образам, мотивам, композициям. Далее, опираясь на полученные данные, выявить черты изобразительного характера, связывающие их с искусством родственных кочевых племен, что позволит подойти к истокам происхождения и выявлению центров производства подобных произведений.

Так, например, С.И. Руденко в своей монографии, посвященной материалам Сибирской коллекции, писал: «Очень важно разобраться в стилистических особенностях южносибирского искусства, представленного Сибирской коллекцией, так как они могут помочь в определении времени изготовления отдельных вещей и до некоторой степени в выяснении принадлежности их той или иной этнической среде» $[15$, с. 30$]$. В то же время М.П. Грязнов отмечал: «Нельзя дать правильную оценку стиля и исполнения, если мы не знаем изображенного животного» [1, с. 498500]. Но при этом важно правильно определить мотив изображения и видовую принадлежность персонажа, так как в обратном случае это приведет к неверным выводам не только изобразительного характера, но и исторического плана. Так, например, весьма проблематично звучит заключение Л.С. Клейна, что, поскольку исходным районом «сарматского тарандра» были образы, изображенные на изделиях, происходящих из Поишимья и Поиртышья, то именно оттуда происходили миграции сарматских племен на запад [7, с. 229]. Однако, как показало наше исследование, стилистические особенности изображений на рассматриваемых предметах и письменные источники противоречат такому выводу. А если подобное явление и имело место в истории сарматских племен, то для доказательства нужны другие аргументы. Однако решение этого глобального вопроса, требующего специального исследования, выходит за рамки темы данной статьи.

\section{ПРИМЕЧАНИЕ}

${ }^{1}$ Большие фалары утрачены. Сохранились лишь фотографии, в том числе и цветные, а также рисунки. Л.С. Клейн, автор раскопок Садового кургана, отмечает, что вставки на больших фаларах сделаны из бирюзы и гранатов. На цветной фотографии в публикации Л.С. Клейна видно, что в инкрустации фаларов, кроме бирюзы, присутствуют вставки красноватого оттенка, но были ли они сделаны действительно из гранатов или из красного стекла, мы уже, к сожалению, никогда не узнаем. Однако надо заметить, что в сарматском полихромном зверином стиле вставки из граната фактически не известны. Более вероятно предположить, что в инкрустации больших фаларов использовался сердолик. Например, сочетание вставок из бирюзы и сердолика фиксируется в декоре кинжала из не менее знаменитого кургана Дачи. Малые фалары сохранились полностью и находятся в коллекции Ростовского областного краеведческого музея, инв. № КП2533-2536/26-29 [6, с. 128-130; 16, p. 256258 ; 7, c. $228-234 ; 8$, c. $100-115 ; 17$, p. $54-61 ; 13$, c. $88-$ $89 ; 14$, с. $77 ; 4$, с. $141-143$, ил. 70,6 ; 5 , с. $100-101$, рис. 2,1 ; и др.]. 


\section{РАННИЙ ЖЕЛЕЗНЫЙ ВЕК}

\section{ПРИЛОЖЕНИЯ}

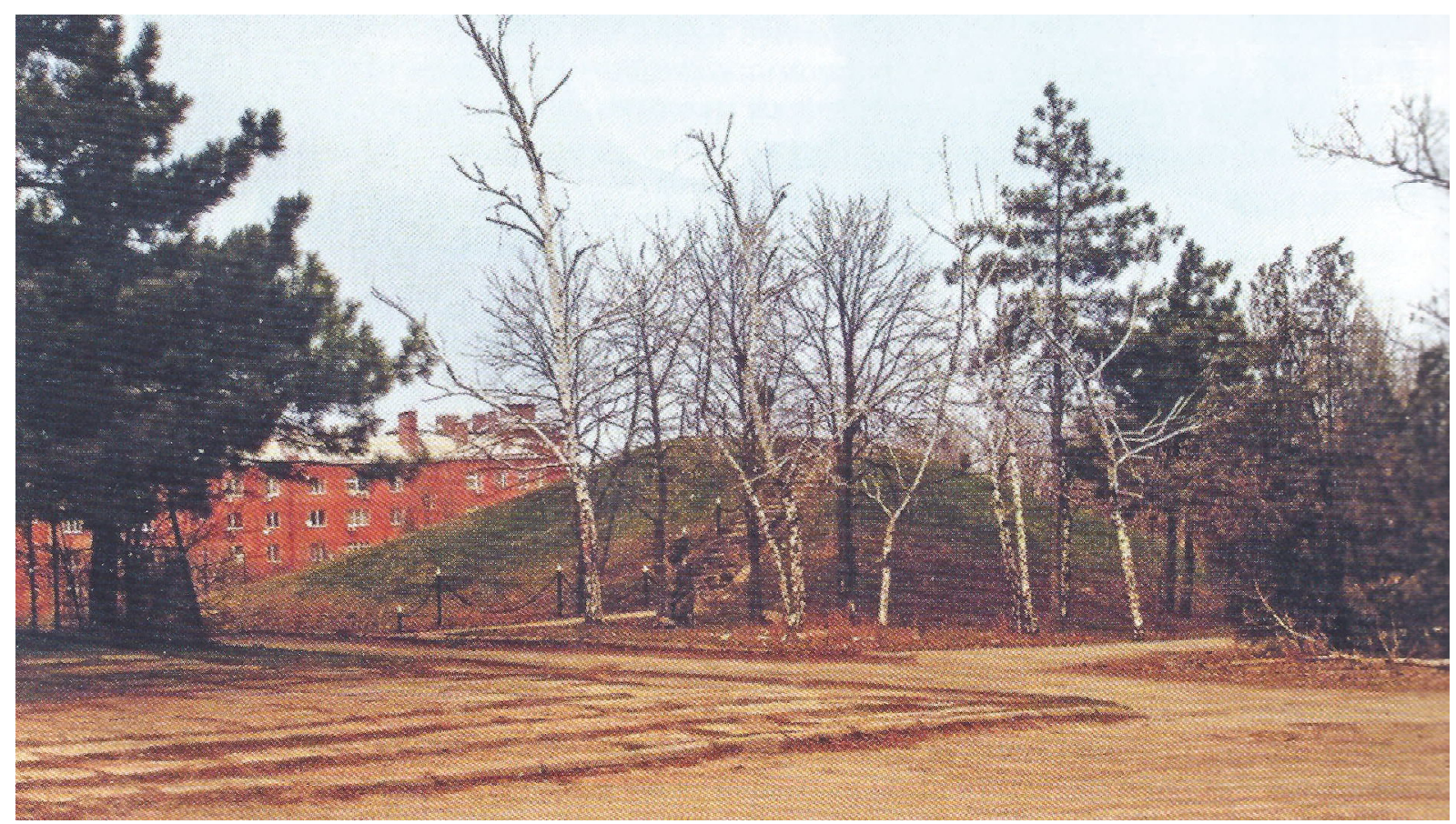

Рис. 1. Окрестности города Новочеркасска - вид на курган Садовый (по публикации И.П. Засецкой: [4, с. 14])

Fig. 1. The precincts of Novocherkassk - the view of the mound Sadovy (from the publication by I.P. Zasetskaya: [4, p. 14]) 


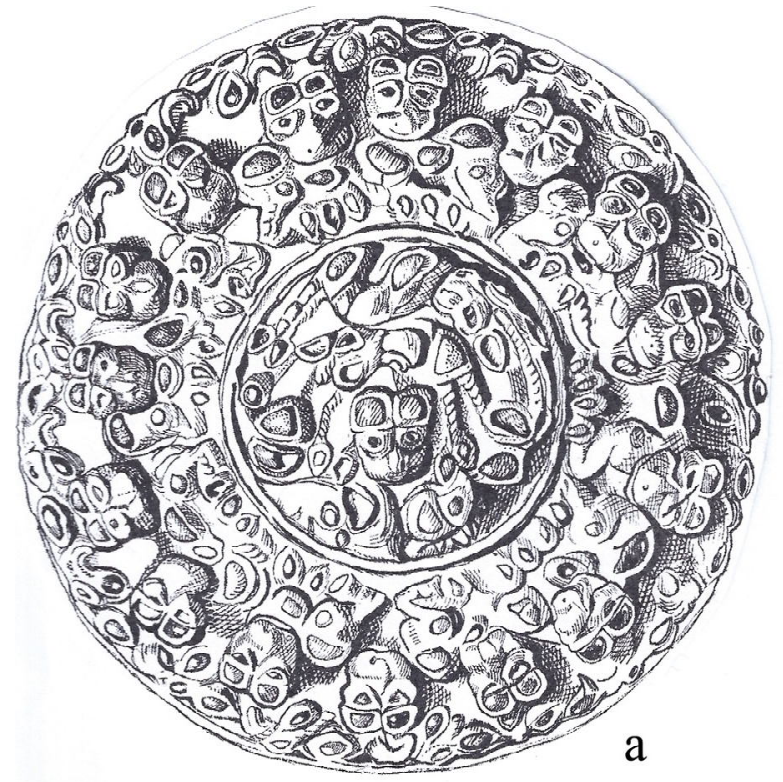

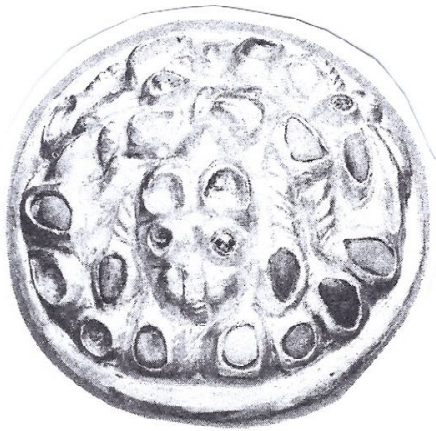

6

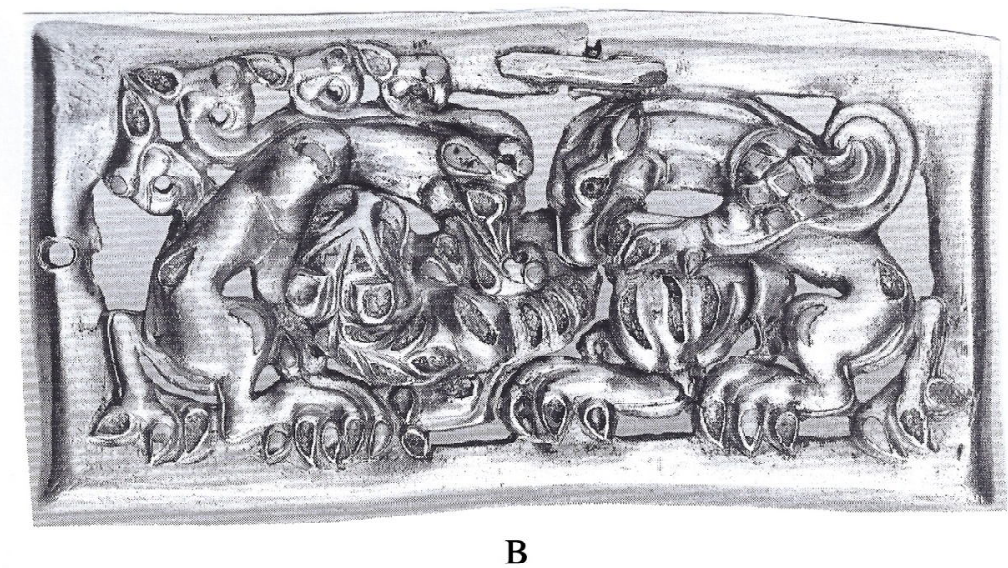

Рис. 2. Сцены жертвоприношения или терзания:

$a, \sigma$ - изображения на больших и малых фаларах из кургана Садового; в - золотая поясная пластина из Сибирской коллекции Петра I

Fig. 2. The scenes of sacrifice or torment:

$a, b$ - the images on large and small phalerae from the mound Sadovy; $c$ - the golden waist plate from the Siberian collection of Peter the Great 


\section{РАННИЙ ЖЕЛЕЗНЫЙ ВЕК}

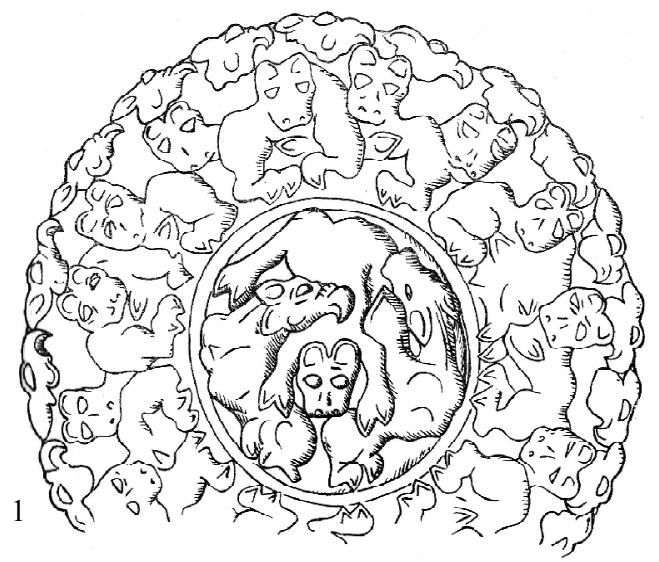

3
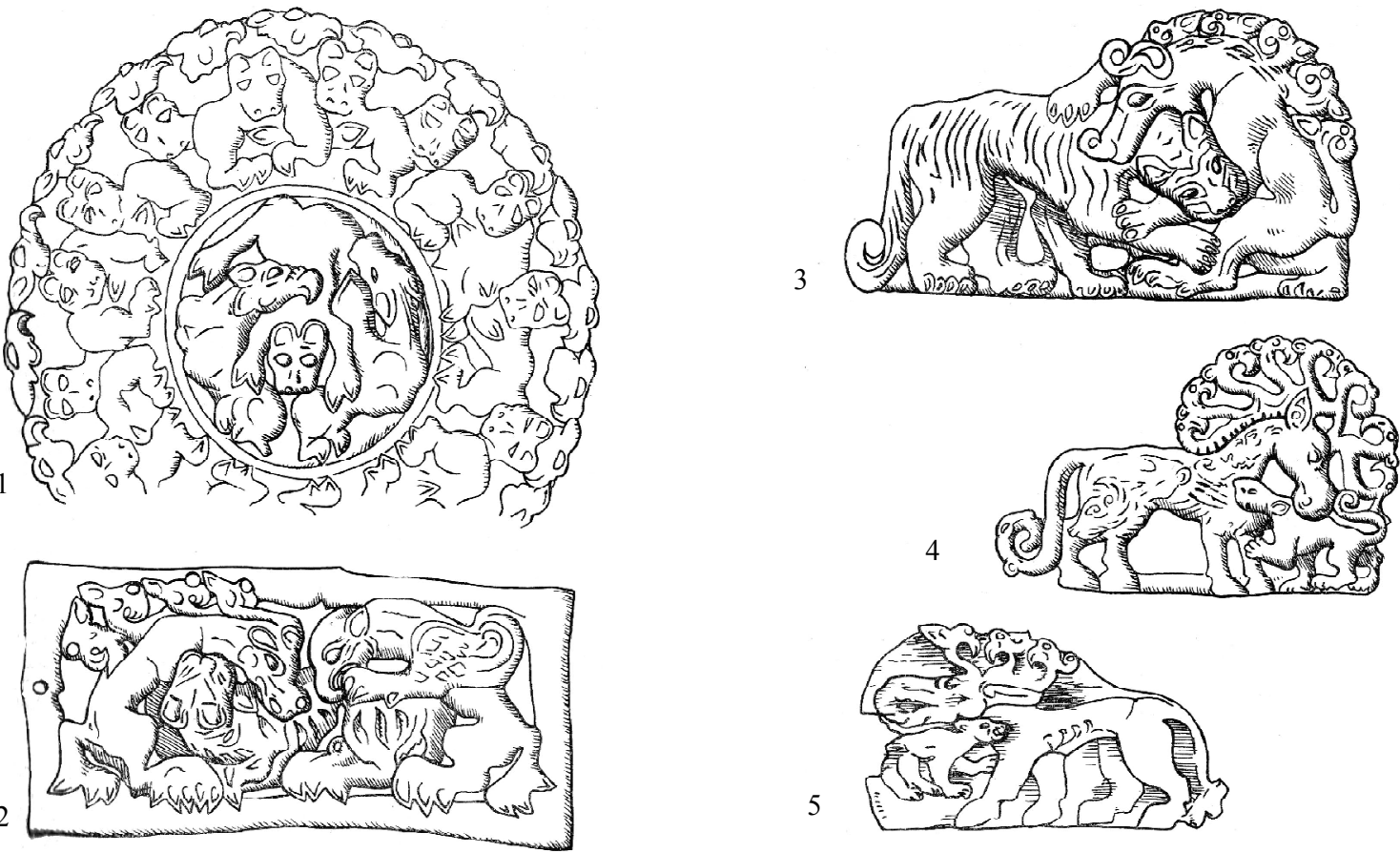

Рис. 3. Рисунок 1 из публикации Л.С. Клейна 1976 г.

«Изображения тарандра и его прототипа в сценах терзания:

1 - фалар из Садового кургана; 2 - бляха-застежка из декабрьской посылки Гагарина;

3 - бляха-застежка из январской посылки Гагарина; 4 - бляха из Улан-Уде;

5 - деревянная бляха из Катанды (схематизированные прориси)»

Fig. 3. Picture 1 from the publication by L.S. Klein 1976

"The images of tarandrus and its prototype in the scenes of torment:

1 - phalerae from the mound Sadovy; 2 - the buckle-clasp from the December's parcel of Gagarin;

3 - the buckle-clasp from the January's parcel of Gagarin; 4 - the buckle from Ulan-Ude;

5 - the wooden buckle from the Katanda city (schematized drawings)" 


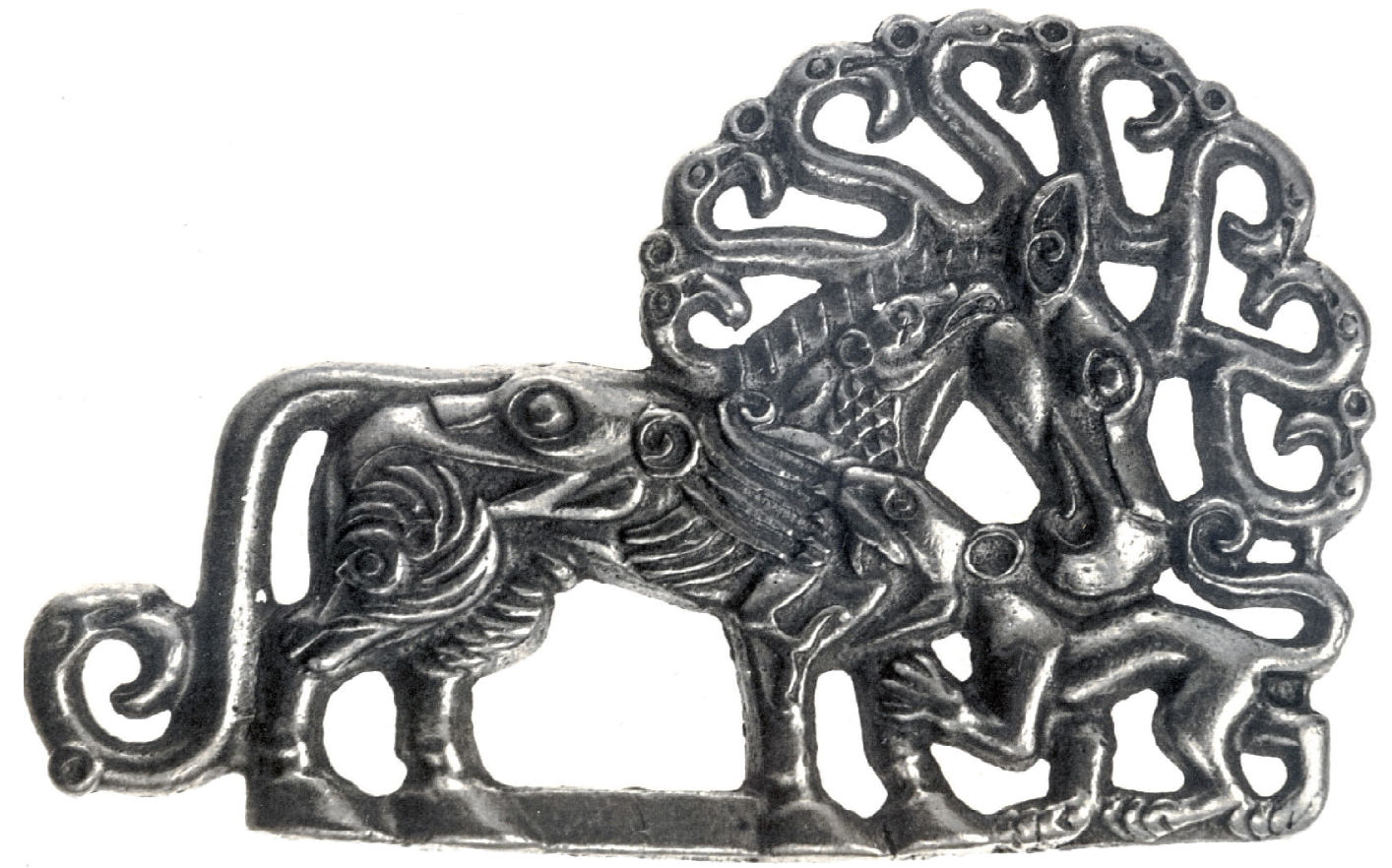

a

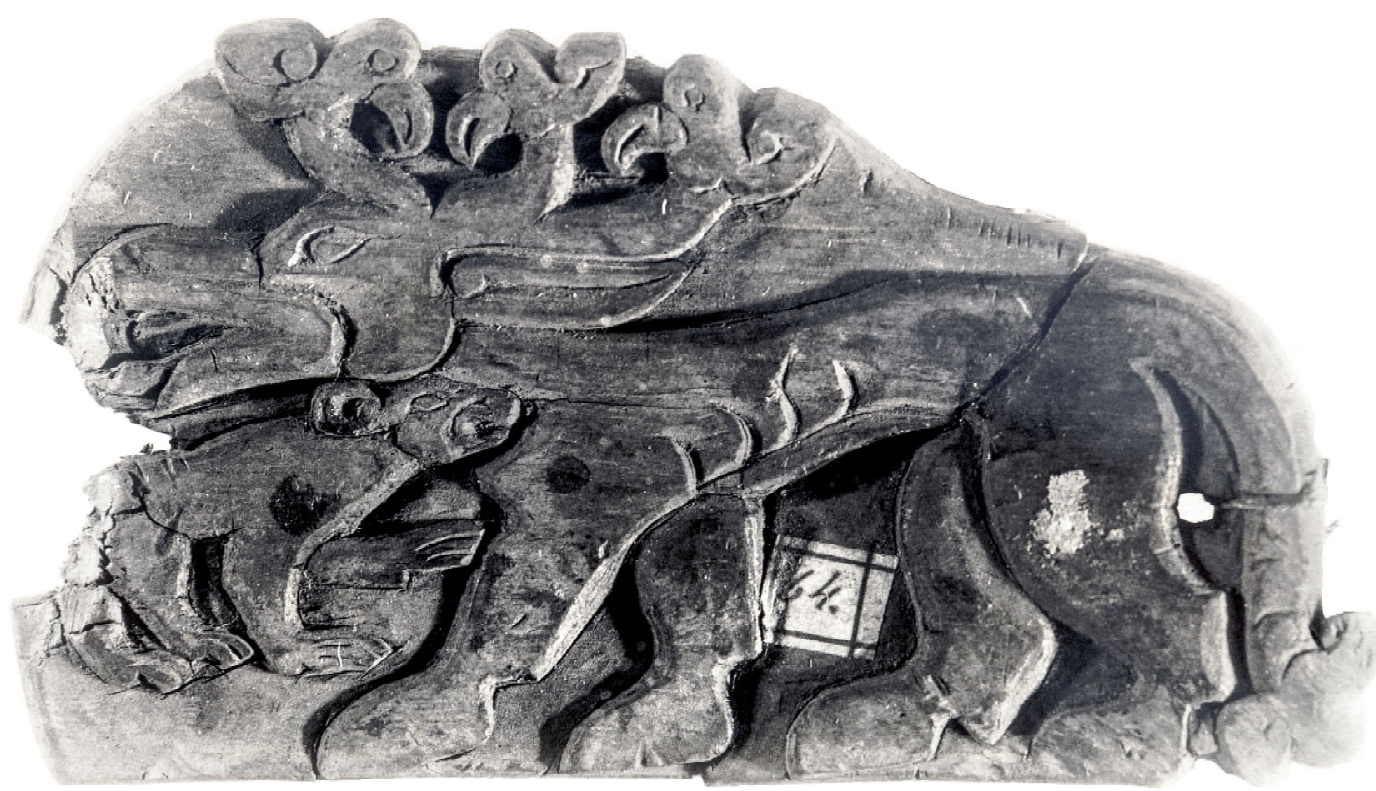

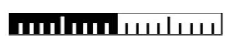

б

Рис. 4. Сцены нападения:

$a$ - золотая пластина от парной застежки из Улан-Уде (Сибирская коллекция Петра I);

$\sigma$ - деревянная пластина - часть застежки из кургана у г. Котанды

Fig. 4. The scenes of assault:

$a$ - the golden plate from the pair clasp from Ulan-Ude. The Siberian collection of Peter the Great; $b$ - the wooden plate - part of the clasp from the mound near the Katanda city 


\section{СПИСОК ЛИТЕРАТУРЫ}

1. Грязнов, М. П. Пазырык. Погребение племенного вождя на Алтае : дис. ... д-ра ист. наук / Грязнов Михаил Петрович // Архив Отдела археологии Восточной Европы и Сибири Государственного Эрмитажа. - 1945. (Рукопись).

2. Завитухина, М. П. Золотая пластина из Забайкалья и Сибирской коллекции Петра I / М. П. Завитухина // Древние культуры Центральной Азии и Санкт-Петербург : материалы Всерос. науч. конф., посвящ. 70-летию со дня рождения А. Д. Грача. СПб. : Культ-информ-пресс, 1998. - С. 143-148.

3. Засецкая, И. П. Изображение пантеры в сарматском искусстве / И. П. Засецкая // Советская археология. -1980 . - № 1. - С. 46-55.

4. Засецкая, И. П. Сокровища кургана Хохлач. Новочеркасский клад / И. П. Засецкая. - СПб. : Изд-во Гос. Эрмитажа, 2011. -328 с.

5. Засецкая, И. П. Украшения конской сбруи из сарматских погребений І в. н. э. / И. П. Засецкая // Scripta Antiqua : Альманах. T. 2. - М. : Собрание, 2012. - C. 96-126.

6. Капошина, С. И. Ценные находки археологов в районе Новочеркасска / С. И. Капошина // Вестник Академии наук. - 1963. - № 3. - С. 128-130.

7. Клейн, Л. С. Сарматский тарандр и вопрос происхождения сарматов / Л. С. Клейн // Скифосибирский звериный стиль в искусстве народов Евразии. - М. : Наука, 1976. - С. 228-234.

8. Клейн, Л. С. Первый век. Сокровища сарматских курганов / Л. С. Клейн. - СПб. : Евразия, 2016. -224 c.

9. Королькова, Е. Ф. Звериный стиль Евразии : Искусство племен Нижнего Поволжья и Южного Приуралья в скифскую эпоху / Е. Ф. Королькова. СПб. : Петербургское Востоковедение, 2006. - 272 с.

10. Латышев, В.В.Известия древних писателей греческих и латинских о Скифии и Кавказе / В. В. Латышев. - Т. І, вып. 1. - СПб. : Типография Императорской академии наук, 1890. - 946 с.

11. Латышев, В. В. Известия древних писателей греческих и латинских о Скифии и Кавказе / В. В. Латышев. - Т. II, вып. 1. - СПб. : Типография Императорской академии наук, 1904. - 271 с.

12. Минасян, Р. С. Металлообработка в древности и средневековье / Р. С. Минасян. - СПб. : Изд-во Гос. Эрмитажа, 2014. -471 с.

13. Мордвинцева, В. И. Полихромный звериный стиль / В. И. Мордвинцева. - Симферополь : Универсум, 2003. - 216 с.

14. Мордвинцева, В. И. Произведения торевтики и ювелирного искусства в Северном Причерноморье, ІІ в. до н. э. - ІІ в. н. э. Т. ІІ / В. И. Мордвинцева, М. Ю. Трейстер. - Симферополь ; Бонн : Тарпан, 2007. -255 с.
15. Руденко, С. И. Сибирская коллекция Петра I / С. И. Руденко. - М. ; Л. : Изд-во АН СССР, 1962. 52 с. - (Свод археологических источников ; вып. Д3-9).

16. Kaposhina, S. I. A Sarmatian Royal Burial at Novocherkassk / S. I. Kaposhina // Antiquity. - XXXVI, № 148. - 1963. - P. 256-258.

17. Treister, M. About the Centres Manufachture of Certain Series of Horse-Harness Roundels in «GoldTurquoise Animal Styl» of the 1-2 Centuries A.D. / M. Treister, S. Yatsenko // Silk Road Art and Arhaeology. - 1997/ 1998. - 5. - P. 51-106.

18. Zaseckaja I. P. On the Question of the Existence «Sarmatian Tarandus» in the Animal Style Art of the South Russian Steppe Nomads in the $2^{\text {nd }}$ century BC $-2^{\text {nd }}$ century A.D. / I. P. Zaseckaja // Lebenswelten Zwischen Archäologie und Geschichte Festschrift für Falko Daim zu Seinem 65. Geburtstag. Mainz, 2018. - P. 489-494.

\section{REFERENCES}

1. Gryaznov M.P. Pazyryk. Pogrebenie plemennogo vozhdya na Altae: dis. ... d-ra ist. nauk [Pazyryk. The Burial of a Tribal Chiefman in the Altai. Dr. hist. sci. diss.]. Leningrad, 1945. 593 p.

2. Zavitukhina M.P. Zolotaya plastina iz Zabaykalya i Sibirskoy kollektsii Petra I [The Golden plate from the Trans-Baikal area and the Siberian collection of Peter I]. Drevnie kultury Tsentralnoy Azii i Sankt-Peterburg. Materialy vserossiyskoy nauchnoy konferentsii, posvyashchennoy 70-letiyu so dnya rozhdeniya A.D. Gracha [Ancient Cultures of Central Asia and Saint Petersburg. Proceedings of the allRussian Academic Conference Dedicated to the $70^{\text {th }}$ Birth Anniversary of A. D. Grach]. Saint Petersburg, Kult-inform-press, 1998, pp. 143-148.

3. Zasetskaya I.P. Izobrazhenie pantery v sarmatskom iskusstve [The Image of a Panther in the Sarmatian Art]. Sovetskaya arkheologiya [Soviet Archaeology], 1980, no. 1, pp. 46-55.

4. Zasetskaya I.P. Sokrovishcha kurgana Khokhlach. Novocherkasskiy klad [The Treasures of the Khokhlach Mound. The Hoard of Novocherkassk]. Saint Petersburg, State Hermitage Publ., 2011.328 p.

5. Zasetskaya I.P. Ukrasheniya konskoy sbrui iz sarmatskikh pogrebeniy I v. n. e. [Decoration of a Horse Harness from Sarmatian Burials of the $1^{\text {st }}$ Century AD]. Scripta Antiqua. Almanakh. Moscow, Sobranie Publ., 2012, vol. 2, pp. 96-126.

6. Kaposhina S.I. Tsennye nakhodki arkheologov v rayone Novocherkasska [The Valuable Finds of Archaeologists in the Novocherkassk Area]. Vestnik Akademii Nauk [Bulletin of the Academy of Sciences], 1963, no. 3, pp. 128-130. 
7. Klein L.S. Sarmatskiy tarandr i vopros proiskhozhdeniya sarmatov [The Sarmatian Tarandrus and the Issue of the Origin of the Sarmatians]. Skifosibirskiy zverinyy stil $v$ iskusstve narodov Evrazii [Scythian-Siberian Animal Style in the Art of Eurasia's Population]. Moscow, Nauka Publ., 1976, pp. 228-234.

8. Klein L.S. Pervyy vek. Sokrovishcha sarmatskikh kurganov [The First Century. Treasures of the Sarmatian Mounds]. Saint Petersburg, Evraziya Publ., 2016. 224 p.

9. Korolkova E.F. Zverinyy stil Evrazii. Iskusstvo plemen Nizhnego Povolzhya i Yuzhnogo Priuralya v skifskuyu epokhu [The Animal Style of Eurasia. The Art of the Tribes of the Lower Volga and Southern Urals in the Scythian Era]. Saint Petersburg, Peterburgskoe Vostokovedenie Publ., 2006. 272 p.

10. Latyshev V.V. Izvestiya drevnikh pisateley grecheskikh i latinskikh o Skifii i Kavkaze [News of Ancient Greek and Latin Writers about Scythia and the Caucasus]. Saint Petersburg, Tipografiya Imperatorskoy akademii nauk, 1890, vol. I, iss. 1. $946 \mathrm{p}$.

11. Latyshev V.V. Izvestiya drevnikh pisateley grecheskikh i latinskikh o Skifii i Kavkaze [News of Ancient Greek and Latin Writers about Scythia and the Caucasus]. Saint Petersburg, Tipografiya Imperatorskoy akademii nauk, 1904, vol. II, iss. 1. $271 \mathrm{p}$.

12. Minasyan R.S. Metalloobrabotka v drevnosti i srednevekovye [Metalworking in Antiquity and in the Middle Ages]. Saint Petersburg, State Hermitage Publ., 2014. 471 p.

13. Mordvintseva V.I. Polikhromnyy zverinyy stil [Polychrome Animal Style]. Simferopol, Universum Publ., 2003. 216 p.

14. Mordvintseva V.I., Treyster, M.Yu. Proizvedeniya torevtiki i yuvelirnogo iskusstva $v$ Severnom Prichernomorye. II v. do n. e. - II v. n. e. [Works of Toreutics and Jewelry Art in the Northern Black Sea Region in the $2^{\text {nd }} c . B C-2^{\text {nd }} c$. AD]. Simferopol; Bonn, Tarpan Publ., 2007, vol. II. 255 p.

15. Rudenko S.I. Sibirskaya kollektsiya Petra I [The Siberian Collection of Peter the Great]. Svod arkheologicheskikh istochnikov [Archaeological Sources]. Moscow; Leningrad, 1962, iss. D3-9. 52 p. +27 tables.

16. Kaposhina S.I. The Sarmatian Royal Burial in Novocherkassk. Antiquity, 1963, vol. XXXVI, no. 148, pp. 256-258.

17. Treister M., Yatsenko S. About the Centres Manufachture of Certain Series of Horse-Harness Roundels in 'Gold-Turquoise Animal Style' of the $1^{\text {st }}$ $2^{\text {nd }}$ Centuries AD. Silk Road Art and Archaeology, 1997 / 1998, no. 5, pp. 51-106.

18. Zasetskaya I.P. On the Existence of 'Sarmatian Tarandus' in the Animal Style Art of the South Russian Steppe Nomads in the $2^{\text {nd }}$ century DC $-2^{\text {nd }}$ century AD. Lebenswelten Zwischen Archäologie und Geschichte Festschrift für Falko Daim zu Seinem 65. Geburtstag. Mainz, 2018, pp. 489-494.

\section{Information about the Author}

Irina P. Zasetskaya, Doctor of Sciences (History), Chief Researcher, Department of Archaeology of Eastern Europe and Siberia, State Hermitage Museum, Dvortsovaya Emb., 34, 194000 Saint Petersburg, Russian Federation, krokochka1@mail.ru, https:/orcid.org/0000-0002-1313-3502

\section{Информация об авторе}

Ирина Петровна Засецкая, доктор исторических наук, главный научный сотрудник Отдела археологии Восточной Европы и Сибири, Государственный Эрмитаж, Дворцовая наб., 34, 194000 г. Санкт-Петербург, Российская Федерация, krokochka1@mail.ru, https://orcid.org/0000-0002-1313-3502 